\title{
THE EXPERT OPINION ON QUALITY OF FAMILY FUNCTIONING IN CROATIA
}

\author{
Dr. Ivana Visković, University of Split, Faculty of Humanities and Social Sciences, Croatia \\ E-mail: iviskovic@ffst.hr \\ Dr. Maja Ljubetić, University of Split, Faculty of Humanities and Social Sciences, Croatia \\ E-mail: ljubetic@ffst.hr
}

\section{A R T I C L E I N F O}

Original Research

Received: June, 26.2019.

Revised: November, 11.2019.

Accepted: November, 17.2019.

doi: 10.5937/IJCRSEE1903001V

UDK

37.018.1(497.5)

$159.923 .2 .072-053.2 / .6(497.5)$

Keywords:

certain aspects of the educational

function,

Delphi method,

educational outcomes,

family,

family functions,

family relationship,

parenting.

\section{A B S T R A C T}

A number of recent studies found the link between the quality of family functioning, welfare and children's achievement. In the absence of longitudinal studies on the quality of family functioning in Croatia, the expert opinion on family functions and the educational aspects of family life was explored. The data was obtained by classic Delphi method, in three cycles. Anonymous discussion was accepted as a quality manner of idea generating and analysis. Socio-emotional and upbringing functions have been singled out as the most significant permanent family functions, while the educational function is gradually taken over by the society. The expert opinion on family functions and the educational aspects of family life in Croatia was explored. The development of self-esteem and self-respect in children has been identified as the most important aspect of the upbringing function of family. It is assumed that the quality of growing up is related to growing up in families with family functioning. Research participants anticipate further changes in the family structure and the way that family functions. There was no consensus on the unambiguous definition of the family as a concept. There was no statistically significant difference between the opinions of the research participants on the importance of individual family functions in the modern society, and the predictors of the quality of family life. Due to the long-term economic crisis, there is a justified concern about the quality of parenting and, subsequently, the current and long-term welfare of children.

(C) 2019 IJCRSEE. All rights reserved.

\section{INTRODUCTION}

The family is a unique community determined by the structure and functions it meets in order to respond to the needs of its members. Structurally, family is an (un) conscious network of interactive relationships between children and parents. Every family member responds, openly or latently, to the processes and changes, events and possible pressures on and within family, and this process is bidirectional - the reaction of an individual reflects on the entire family. If we paraphrase Watzlawick's rules of communication (Watzlawick, 1993), we can

Corresponding Author

Dr. Ivana Visković, University of Split, Faculty of

Humanities and Social Sciences, Croatia

E-mail: iviskovic@ffst.hr

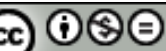

This work is licensed under a Creative Commons Attribution - NonCommercial - NoDerivs 4.0. The article is published with Open Access at www.ijcrsee.com assume there are family influences even when there are no visible manifestations of family interaction (for example, children who grow up outside the family, without parental care).

Particular family relationships between (biologically or socially conditioned) children and (heterosexual or homosexual) parents with the (im) permeability of family boundaries, direct the understanding of the family as an interactive social construct. The quality of family life is recognizable for ways in which the family meets their functions, and meets the needs of its members (Belsky, et al., 2012; Olson, 2011; Vandell, et al., 2010):

- Interconnections in the family (cohesiveness) through which family members meets their needs for love, belonging, closeness, and attachment. This can be seen in the level of mutual trust, emotional expressiveness, ways in which family members spend time with each other, caring behaviours, individuals' balance, ways of planning, decision-making and actions, and ways of solving problems. 
- Flexibility as a family's ability to adapt to developmental cycles, family processes and possible stressful situations, crises and traumas, as well as everyday situations. The boundaries of family and the permeability of borders in relation to the social environment referred to in the forms of leadership.

- Power allocation methods that are recognizable in decision-making and solving problems.

- Communication as an operational modality of family cohesion, flexibility, and parenting style, recognizable in emotional expressions.

The family functions are a nonlinear dynamic system. Changes (in relations, structures, and ways in which functions are performed) are expected, but not clearly predictable. Children are particularly vulnerable to the changes in family life. The development of the child's personality, independence, self-respect, and self-esteem, as well as their socio-emotional, cognitive, and communicative competences is linked to the quality of family functioning. However, this connection is not always linearly causal.

In order to adequately respond to the needs of its members, the family meets a number of functions. Apart from the economic function, which some theorists in the absence of real evidence claim to be the cause of the emergence of family, reproductive-biological, socio-emotional, and educational functions can be recognized. Some functions are modified in accordance with social changes (e.g. living together, care and protection), and some are taken over by the society (e.g. caring for the old and helpless members). The function of early education and care, and that of formal education, is increasingly taken over by the society. However, this does not diminish the educational function of family, which is linked with all other functions.

The modern family lives relatively alone, which most often leads to the absence of support from the family social network. Busy life of parents, as a rule, leads to the institutionalization of childhood. It is reasonable to assume that during early childhood, some children will spend more time with professionals than with their parents. Higher education of employed mothers is in a positive correlation with a smaller number of children in the family (Eurostat, 2018), and in a negative correlation with the maternal care time (D'Addato, 2010; Vandell, et al., 2010). At the same time, fathers are getting more and more involved in the care of their children.
Family relationships are (prevailingly) egalitarian, and parents care for their children together, which can contribute to the synergy of togetherness and the wellbeing of children in the family. Children are getting more and more accepted as active and equal members of family functioning and the development of independence which is encouraged according to their age. This can contribute to the personal satisfaction of family members and the quality of family functioning and indirectly, the quality of growing up in the family (Amato, 2012).

The conditions of growing up and education in the family are largely related to the family's economic status, which also reflects on the quality of parenting. The longterm economic crisis in Croatia undeniably affects the family and the quality of family functioning. The number of families living in poverty and those at risk of poverty is growing. It is estimated that in the Republic of Croatia $26.6 \%$ of children aged $0-17$ are living at risk of poverty (Eurostat, 2018), and every third settlement (town and village) in Croatia has no organized institutional education for children of early and preschool age (Ministry of Science and Education, 2019). At the same time, young people are increasingly leaving Croatia: as much as 36000 mostly young people left during 2017 alone (Croatian Bureau of Statistics, 2018). This data facts points to complex problems that are also reflects the quality of family functioning

The purpose of this research was to understand the family, to recognize and evaluate family functions and educational aspects of the family life, currently in Croatia.

\section{MATERIALS AND METHODS}

The current dispute scientists are reduced solely to the definition of family (by family members). The contextual family conditions associated with the children's welfare and their educational outcomes are neglected. Without the ability to conduct a longitudinal study we explored the experts' opinion in Croatia.

Bearing in mind differences in the professional experience of the participants, it was assumed that there is a statistically significant difference between the research participants (scientists and practitioners) in their estimations of the importance of individual family functions, individual aspects of the educational role of family, and the quality of parenting for the child's growing up.

An empirical non-experimental research 
of expert opinion was conducted using the classic Delphi method through three cycles. Two important reasons have led to the choice of the Delphi method: the difficulty of selecting a representative sample of families in Croatia and the presumed tendency to give desirable answers regarding self-evaluation of the quality of personal family functioning.

The Delphi method implies a scientific approach through the process of conducting a survey and discussion among anonymous participants during two or more cycles (Visković, 2016). It is applied in situations where, in the absence of relevant data, the opinion of experts is researched. The research involved scientists and practitioners to compare the perception of individuals who are supposed to have scientific insights and those who have insights into the practice. The collected data is processed between each cycle (measures of central tendency and estimation direction) and submitted to the participants for further consideration and evaluation by the research subjects and generation of new ideas. The anonymous discussion about new ideas and/or different argumentative statements was for which no prior consent has been obtained. The aim was not necessarily to achieve consensus among the participants, but to collect the arguments that could contribute to the understanding of the subject matter of the research (Green, 2014).

In the construction of the research instrument, a combined approach was used: the evaluation of existing scientific theses, the possibility of proposing and evaluating new claims. In order for participants to focus on the research problem, the first-cycle instrument was constructed based on the theoretical analysis of the recent sources, without reference to the sources so that participants can impartially evaluate theses rather than authors. The first-cycle instrument included existing family definitions, family functions (18 items), aspects of the educational role of family (19 items) and predictors of the quality of family functioning (17 items). The estimation was possible on a 6-degree scale (ranging from $1=$ completely insignificant to 6 $=$ very significant). Research participants were encouraged to create and argue their personal as well as their scientific and professional views. Generated statements were offered to the participants in the second and third cycle instruments for discussion and evaluation. The reliability of the instrument was determined using Cronbach's Alpha and is high $(\alpha=.86$ for 126 items). It is different for each phase of the research. The reliability of the firstcycle instrument is $\alpha=.85$ (54 items), second $\alpha=.89$ (42 items), and $\alpha=.86$ (29 items) for the instrument of the third cycle of research. This paper presents some of the findings of processed data from the first cycle and generated statements of individual research participants.

On the assumption that heterogeneous groups, by using the Delphi method, generate more accurate judgments than experts in homogeneous groups (van der Schaaf and Stokking, 2011), experts of different profiles were gathered in this research. The participants of this research have, in their professional work, an insight into family functioning and children's outcomes or they are involved in family support. The sample is intentional and stratified according to scientific and professional areas. It includes 15 scientists and 19 practitioners, 28 of which are women, and 6 are men. During the research the participants are mutually anonymous (they do not know who are participates in the research). Allowed their identity to be disclosed after the research was finished: Ph.D. Sandra Antulić, National Center for External Valuation of Education, Zagreb; Ivona Beus Riechtenberg, political scientist, EU Parlament; Ph.D. Andreja Brajša Žganec, Institute of Social Sciences Ivo Pilar, Zagreb; Maja Flego, PR, Offices of Ombudsman for Children, Croatia; Ma. Maja Gabelica Šupljika, Offices of Ombudsman for Children, Croatia; Ph.D. Josip Janković, emeritus; Stjepan Lice, Faculty of Law, University of Zagreb; Ph.D. Anka Lozančić, Faculty of Teacher Education, University of Zagreb; Ph.D. Anita Mandarić Vukušić, Faculty of Humanities and Social Sciences, University of Split; Ph.D. Arjana Miljak, emeritus; Ph.D. Branko Rafajac, Full Prof., Faculty of Humanities and Social Sciences, University of Rijeka; Ph.D. Majda Rijavec, Full Prof., Faculty of Teacher Education, University of Zagreb; Ph.D. Edita Rogulj, Faculty of Teacher Education, University of Zagreb; Ph.D. Edita Slunjski, Full Prof., Faculty of Humanities and Social Sciences, University of Zagreb; Ph.D. Vedrana Spajić Vrkaš, Full Prof., Faculty of Humanities and Social Sciences, University of Zagreb; - Ph.D. Adrijana Višnjić Jeftić, Ass.prof., Faculty of Teacher Education, University of Zagreb. The relative majority of the research participants are pedagogues $(41.17 \%, \mathrm{~N}=14)$. There were also 8 psychologists $(23.52 \%$ of the research participants), 2 lawyers, 2 political scientists, 2 theologians, one expert in 
education and rehabilitation, one sociologist, one psychiatrist, and one economist. In both subsamples, individual participants have expressed extreme attitudes that could be linked to the area of their activity. The pedagogues expressed their openness to question the attitudes. The theologians have, in both subsamples, expressed and maintained extreme attitudes about individual family functions and educational aspects of family functioning. It is interesting that no participant withdrew from the research, although it was expected that $10 \%$ of the participants, those with extreme views, would withdraw their participation (Visković, 2016).

The Delphi method is primarily focused on a joint discussion and qualitative analysis of the research subject matter. Descriptive statistic is usually used for the Delphi methodmeasurements of central tendency (arithmetic mean/M), deviations (standard deviation/SD) and response dispersion (frequency/f). The estimation direction was analyzed to determine the level of consensus. The existence of a statistically significant difference between the opinions of research participants - scientists and practitioners - was investi-gated by means of a Mann-Whitney $U$. The collected data were processed using the SPSS statistical program/ Statistical Package for Social Sciences 20.0.

\section{RESULTS AND DISCUSSIONS}

\section{The definitions of family}

Some scientists' estimate that it's impossible to unambiguously define the family, which corresponds to the attitude that family life evolves while is gradually changing, to meet the needs more effectively of the society as a whole and each member of the family (Haralambos and Holborn, 2002, p. 503). However, considering the current controversy in Croatia on (not) passing the Family Act because of the definition of family, the participants were asked to give an optimal definition of family. Following the analysis of recent relevant literature, ten family definitions were provided without reference to the source (to ensure that the participants are neutral according to the sources). It is interesting that the definitions of family indicated in legal documents (such as the Law on Social Welfare, $\mathrm{NN}, 157 / 13$ ) were not acceptable to any of the participants. Civil servants included in the sample $(\mathrm{N}=2)$ chose to side with the attitude that family is a close-knit community within the same household, consisting of parents (both or just one) and their non-married children (who are neither legally married nor live in a consensual union), of a man and woman without children or a man and woman who live in a consensual union (for the needs of the population census, made by the Croatian Bureau of Statistics, 2013).

Most research participants $(52.94 \%$, $\mathrm{N}=18$ ) as optimal definition of family accept the view that family is primarily an emotional community. It is justifiable to interpret it as a living system, an ideological and symbolic construct determined primarily by specific emotional relationships (Elkind, 1994). One of the participants (a psychiatrist) emphasizes that the family should be the place for emotional stabilization of adults and the area of emotional safety for children. Reflecting on this statement, two pedagogues estimate these are wishes, but not reality. Stressing the emotional function of a family also generates the attitude that the family should be accepted as a community of individuals that perceive each other as partners (married, extramarital, heterosexual or homosexual), and who are primarily connected to each other emotionally. This view is aligned with the recent world research (Dempsey, 2013). In total 78.9\% of the respondents agree with this statement $(\mathrm{M}=4.31 ; \mathrm{SD}=0.63)$. The theologians in both subsamples strongly disagree with this view.

\section{Family functions}

After analyzing the family functions, the research participants have assessed (Table 1.) that the most significant family function is the psychological function, upbringing function, and socialization. The patriotic and the religious function of family were singled out as the least significant family functions in Croatia today. At the same time, in social reality of Croatia, the conservative and religious/dogmatic tendencies are increasing which correlates religiousness more to dogmatism than to spirituality. Some organizations advocate defining family solely as a community of heterosexual partners, emphasizing the patriotic and religious functions as primary. 
Table 1. The estimation of significance of family functions (for the whole sample)

\begin{tabular}{|c|c|c|c|c|c|c|}
\hline Family function & $\min$ & $\max$ & $\mathrm{M}$ & SD & $\mathrm{S}$ & $\mathrm{K}$ \\
\hline $\begin{array}{l}\text { psychological } \\
\text { function * }\end{array}$ & 2 & 6 & 4.81 & 0.99 & -0.84 & 0.75 \\
\hline Socialization ${ }^{*}$ & 2 & 6 & 4.50 & 1.22 & -0.62 & -0.31 \\
\hline $\begin{array}{l}\text { care and } \\
\text { protection of } \\
\text { children and } \\
\text { young } \\
\text { people * }\end{array}$ & 2 & 6 & 4.50 & 1.29 & -0.57 & -0.08 \\
\hline $\begin{array}{l}\text { upbringing } \\
\text { function * }\end{array}$ & 2 & 8 & 4.50 & 1.34 & 0.17 & 0.16 \\
\hline $\begin{array}{l}\text { protective } \\
\text { function* }\end{array}$ & 2 & 6 & 4.30 & 1.13 & -0.09 & -0.49 \\
\hline uctive & 2 & 6 & 4.15 & 1.17 & -0.06 & -0.60 \\
\hline $\operatorname{mic}$ & 2 & 6 & 4.09 & 1.08 & 0.12 & -0.37 \\
\hline ional & 2 & 6 & 4.00 & 1.16 & -0.14 & -0.96 \\
\hline $\begin{array}{l}\text { living together } \\
*:\end{array}$ & 1 & 6 & 3.97 & 1.28 & -0.33 & -0.18 \\
\hline $\begin{array}{l}\text { emotional } \\
\text { stabilization of } \\
\text { adults ** }\end{array}$ & 1 & 6 & 3.81 & 1.38 & -0.43 & -0.19 \\
\hline moral function & 1 & 6 & 3.72 & 1.35 & -0.20 & -0.44 \\
\hline $\begin{array}{l}\text { providing social } \\
\text { status * }\end{array}$ & 2 & 6 & 3.71 & 1.24 & 0.04 & -1.01 \\
\hline $\begin{array}{l}\text { knowledge } \\
\text { transfer ** }\end{array}$ & 1 & 6 & 3.63 & 1.29 & -0.10 & -0.72 \\
\hline tradition transfer & 2 & 6 & 3.59 & 1.16 & 0.22 & -0.52 \\
\hline $\begin{array}{l}\text { religious function } \\
* *\end{array}$ & 1 & 6 & 3.50 & 1.27 & 0.25 & 0.10 \\
\hline $\begin{array}{l}\text { biological } \\
\text { function** }\end{array}$ & 1 & 6 & 3.42 & 1.39 & -0.09 & -0.53 \\
\hline $\begin{array}{l}\text { cultural function } \\
* *\end{array}$ & 1 & 6 & 3.31 & 1.21 & 0.65 & 0.57 \\
\hline $\begin{array}{l}\text { patriotic function } \\
* \&\end{array}$ & 1 & 6 & 3.31 & 1.28 & 0.05 & -0.06 \\
\hline
\end{tabular}

As an important family function, the economic function was also singled out. This significance is also recognized in studies that link the economic function of family to educational opportunities of young people and their academic achievements (Johnson and Hitlin, 2017; Swartz, McLaughlin and Mortimer, 2017). At the same time, the economic function should encourage the development of the children's financial competences (Bejaković, 2010; Stegeman and Costongs, 2012).

The response data was tested for normal distribution by using a Shapiro-Wilks test for normality (sample smaller than 50) and appears to be normally distributed $(\mathrm{SW}=.97$; $\mathrm{df}=33 ; \mathrm{p}=.76$ ) with homogeneity of variance (Levene's test, $\mathrm{p}>.05$ ).

After analyzing the possible changes in family functions in the future, the research participants have estimated that some family functions (such as: living together, knowledge transfer, and the religious function) will (in next ten years) become less prominent (at least $75 \%$ of estimations in the same direction) in future. They emphasize that satisfying biological needs is no longer a reason for starting a family. At the same time, this does not diminish the educational significance of the biological-reproductive function. Children should be taught responsible sexual behaviour in the family and adopt basic life values (Visković, 2013). Unfortunately this does not happen often, especially in dysfunctional families like families where family members are not very attached to each other, in families where parents take on risky sexual behaviours, and in families of lower socioeconomic status, so these are the dimensions that become risk factors for the emergence of risky behaviour of young people (Helfrich and McWey, 2014; Kalina, et al., 2011). In social reality of Croatia, according to the available data, in 2017, 2520 intentional terminations of pregnancy were performed, of which 58 were performed on minors, and 122 on girls under the age of 20 (Croatian Institute of Public Health, 2018). Unfortunately, it is possible that this is only partial information because most of the intentional terminations of pregnancy, due to public pressures and praying communities in front of the hospitals, are performed outside hospitals.

\section{The quality of family functioning}

Research participants have analyzed the significance of family relationships and the family functioning quality status (Table 2.). The highest significance of the quality functioning families the participants attributed to mutual attachment among family members, emotional, and open communication. As the least significant aspect of the quality functioning families, the participants estimated discipline in terms of complying with the rules, economic status of the family parents' education, and social status of the family. Although the participants expressed doubts concerning the definition of the term, some authors (Miljković, 2010) define discipline as a form of regulation of the child's behaviour (according to self-regulation) as one of the fundamental parental responsibilities and the predictor of the quality of family life. 
Table 2. The estimation of significance of family relationships and the family functioning quality status (for the whole sample)

\begin{tabular}{|c|c|c|c|c|c|}
\hline & $\min$ & $\max$ & $\mathrm{M} \quad \mathrm{SD}$ & $\mathrm{S}$ & $\mathrm{K}$ \\
\hline Mutual attachment * & 3 & 6 & $\begin{array}{lll}5.58 & 0.71\end{array}$ & -1.96 & 4.46 \\
\hline $\begin{array}{l}\text { Emotional } \\
\text { connection between } \\
\text { family members* }\end{array}$ & 2 & 6 & 5.441 .04 & -2.08 & 3.79 \\
\hline $\begin{array}{l}\text { Two-way, open } \\
\text { communication * }\end{array}$ & 3 & 6 & 5.420 .79 & -1.34 & 1.42 \\
\hline Mutual trust * & 3 & 6 & 5.390 .83 & -1.58 & 2.51 \\
\hline $\begin{array}{l}\text { Clear connection } \\
\text { between spouses * }\end{array}$ & 3 & 6 & 5.240 .91 & -1.06 & 0.41 \\
\hline Time spent together & 2 & 6 & 5.120 .99 & -1.27 & 1.80 \\
\hline $\begin{array}{l}\text { Cooperative, } \\
\text { democratic } \\
\text { relationships * }\end{array}$ & 3 & 6 & 5.060 .96 & -0.56 & -0.83 \\
\hline Self-realization * & 3 & 6 & 4.970 .88 & -0.51 & -0.35 \\
\hline Co-parenting * & 2 & 6 & 4.971 .11 & -1.27 & 1.49 \\
\hline $\begin{array}{l}\text { A flexible family } \\
\text { Structure * }\end{array}$ & 3 & 6 & 4.910 .98 & -0.44 & -0.81 \\
\hline $\begin{array}{l}\text { Flexibility of family } \\
\text { roles * }\end{array}$ & 2 & 6 & 4.721 .05 & -0.97 & 1.09 \\
\hline Optimism * & 2 & 6 & 4.661 .09 & -0.50 & -0.39 \\
\hline $\begin{array}{l}\text { The existence and } \\
\text { adherence to norms } \\
\text { * }\end{array}$ & 2 & 6 & 4.521 .18 & -0.28 & -0.99 \\
\hline $\begin{array}{l}\text { Changes in the } \\
\text { family structure* }\end{array}$ & 2 & 6 & 4.411 .11 & -0.43 & -0.23 \\
\hline $\begin{array}{l}\text { The autonomy of } \\
\text { members * }\end{array}$ & 3 & 6 & $\begin{array}{lll}4.33 & 0.92\end{array}$ & 0.27 & -0.62 \\
\hline $\begin{array}{l}\text { Social status of the } \\
\text { Family ** }\end{array}$ & 1 & 6 & 3.881 .14 & -0.15 & 0.43 \\
\hline Economic status* & 1 & 6 & 3.841 .27 & 0.11 & -0.45 \\
\hline $\begin{array}{l}\text { Parents }{ }^{2} \text { education } \\
* *\end{array}$ & 1 & 6 & 3.821 .04 & -0.13 & 0.92 \\
\hline Discipline ** & 1 & 6 & 3.811 .23 & 0.04 & -0.36 \\
\hline
\end{tabular}

The response data was tested for normal distribution by using a Shapiro-Wilks test for normality which appears to be normally distributed $(\mathrm{SW}=.95 ; \mathrm{df}=33 ; \mathrm{p}=.21$.) with homogeneity of variance (Levene's test, $p>$ $.05)$.

Individual family life aspects were analyzed as predictors of the quality of family functioning. By applying Men-Whitney U test, no statistically significant difference in the estimation of scientists or practitioners was found, except for the dimension of optimism $(\mathrm{p}=.02)$.

According to the practitioners, optimism, as a relatively stable general tendency to expect the best outcome (Talović Vorkapić and Jelić Puhalo, 2016; Tucker, Sharp, Van Gundy and Rebellon, 2017; Widmer, 2016), is a more significant predictor of family functioning than it is considered to be according to the scientists.

The economic status of the family members has been recognized as one of the indicators of the quality of family life, which is in accordance with some studies (Bejaković, 2010; Belsky, 2014). There was also a view according to which Family functioning is one of the predictors of the development of individual's career, with which $97 \%$ of the research participants agree. This is also documented by the research findings that link the personal experience of success and life satisfaction with quality family functioning and socio-emotional connection between family members (Kovčo Vukadin, Novak and Križan, 2016; Rogošić, 2015).

\section{The educational function of family}

Participants also estimated that the educational function of family is a significant family function. In the context of modern society, this function can be analyzed separately - upbringing is interpreted as a permanent family function, while education is more and more taken over by the society. But, if we look at education as a responsible use of knowledge and the development of an individual's potential, it is justifiable to analyze the educational aspects of growing up in a family.

Reliability scale of the assessment of the family's educational function $(\mathrm{N}$ of Items $=17$ ) is exceptionally high and is determined by the application of Cronbach's Alpha $(\lambda=.91)$. Kaiser-Meyer-Olkin Measure of Sampling Adequacy (0.79) and the Bartlett's Test of Sphericity $\left(\chi^{2}=657.99 ; \mathrm{df}=136 ; \mathrm{p}<.00\right)$ indicate the homogeneity of the scale suitable for factor analysis. By means of the Rotated Component Matrix (Table 3.), two factors were singled out in the extraction: personality building and socialization, which together account for $76.2 \%$ of the total variance. These factors can be interpreted as the most important aspects of the educational function of the family. 
Table 3. Rotated Component Matrixa

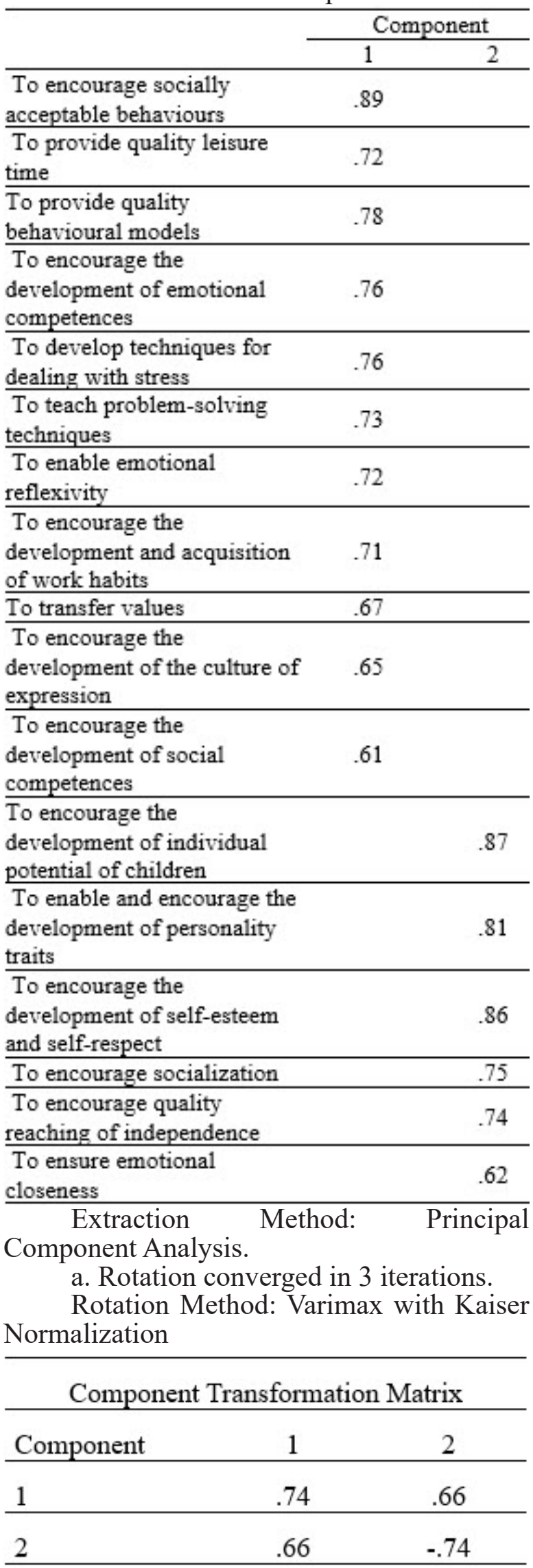

After analyzing the aspects of the educational function of family, the participants have estimated the assurance of emotional closeness to be the most important one (Table 4.). If we accept emotional closeness as one of the dimensions of family relationships, then the development of self-esteem and selfrespect is, according to the estimations, the most significant goal of family upbringing.

Table 4. The significance of certain aspects of the educational function and emotional closeness (for the whole sample)

\begin{tabular}{|c|c|c|c|c|c|c|}
\hline items & $\min$ & $\max$ & $\mathrm{M}$ & SD & $\mathrm{S}$ & $\mathrm{K}$ \\
\hline $\begin{array}{l}\text { To encourage the } \\
\text { development of } \\
\text { self-esteem and } \\
\text { gelf-respect }\end{array}$ & 2 & 6 & 5.51 & 0.78 & -1.43 & 1.06 \\
\hline $\begin{array}{l}\text { To ensure } \\
\text { emotional } \\
\text { closeness }\end{array}$ & 4 & 6 & 5.39 & 0.69 & -1.18 & 0.52 \\
\hline $\begin{array}{l}\text { To encourage the } \\
\text { development of } \\
\text { emotional } \\
\text { competences }\end{array}$ & 4 & 6 & 5.33 & 0.68 & -1.28 & 1.42 \\
\hline $\begin{array}{l}\text { To encourage the } \\
\text { development of } \\
\text { individual } \\
\text { potential of } \\
\text { children }\end{array}$ & 3 & 6 & 5.28 & 0.95 & -1.13 & 0.54 \\
\hline $\begin{array}{l}\text { To encourage } \\
\text { gocialization }\end{array}$ & 3 & 6 & 5,28 & 0.82 & -0.76 & -0.58 \\
\hline $\begin{array}{l}\text { To provide quality } \\
\text { behavioural } \\
\text { models }\end{array}$ & 3 & 6 & 5,28 & 0.89 & -0.63 & -0.77 \\
\hline $\begin{array}{l}\text { To encourage } \\
\text { quality reaching of } \\
\text { independence }\end{array}$ & 3 & 6 & 5,28 & 0.89 & -1.23 & 0.89 \\
\hline $\begin{array}{l}\text { To enable and } \\
\text { encourage the } \\
\text { development of } \\
\text { pergonality traits }\end{array}$ & 4 & 6 & 5,22 & 0.87 & -1.28 & 1.42 \\
\hline $\begin{array}{l}\text { To encourage the } \\
\text { development and } \\
\text { acquisition of } \\
\text { work habits }\end{array}$ & 3 & 6 & 5,22 & 0.87 & -1.04 & 0.26 \\
\hline $\begin{array}{l}\text { To encourage } \\
\text { gocially acceptable } \\
\text { behaviours }\end{array}$ & 3 & 6 & 5.22 & 0.94 & -0.67 & -0.97 \\
\hline $\begin{array}{l}\text { To encourage the } \\
\text { development of } \\
\text { gocial } \\
\text { competences }\end{array}$ & 2 & 6 & 5.11 & 0.91 & -0.67 & -0.56 \\
\hline $\begin{array}{l}\text { To enable } \\
\text { emotional } \\
\text { reflexivity }\end{array}$ & 2 & 6 & 5.11 & 0.91 & -0.94 & 0.19 \\
\hline $\begin{array}{l}\text { To teach problem- } \\
\text { solving techniques }\end{array}$ & 2 & 6 & 4.94 & 0.98 & -0.66 & -0.56 \\
\hline To transfer values & 2 & 6 & 4.78 & 1.31 & -0.76 & -0.42 \\
\hline $\begin{array}{l}\text { To encourage the } \\
\text { development of } \\
\text { the culture of } \\
\text { expression }\end{array}$ & 3 & 6 & 4.72 & 0.82 & -0.34 & -0.67 \\
\hline $\begin{array}{l}\text { To provide quality } \\
\text { leisure time }\end{array}$ & 2 & 6 & 4.61 & 1.09 & -0.39 & -0.76 \\
\hline $\begin{array}{l}\text { To develop } \\
\text { techniques for } \\
\text { dealing with stress }\end{array}$ & 3 & 6 & 4.51 & 1.04 & -0.25 &,- 966 \\
\hline
\end{tabular}

The response data was tested for normal distribution by using a Shapiro-Wilks test for normality and appears to be normally distributed $(\mathrm{SW}=.91 ; \mathrm{df}=33 ; \mathrm{p}=.01)$ with homogeneity of variance (Levene's test, $\mathrm{p}>$ $.05)$.

As the most important aspects of the educational function of family, children 
achieving independency, the development of individual potentials, socially acceptable behaviours, socialization, and the development of emotional competence were also singled out. Research participants have estimated the transfer and development of gender roles to be the least significant aspects of the educational function of family.

By means of the Mann Whitney U test, no statistically significant difference was determined in estimations of the research participants - scientists and practitioners for all subscales (Table 5.). The limit value was perceived in the estimations of importance of family in the development of emotional competences in children and providing quality models of behaviour. Both of the abovementioned aspects of the educational function of family, practitioners evaluate to be more significant than the scientists.

Through an anonymous discussion, the research participants conclude that each family function has an educational significance in the sense of building personality traits, fundamental values, and responsible behaviours in children.

Table 5. Hypothesis Test Summary (Independent Samples Mann-Whitney U Test)

\begin{tabular}{cccccccc}
\hline \multicolumn{2}{c}{ range } & $\min$ & $\max$ & $\mathrm{M}$ & $\mathrm{SD}$ & $\mathrm{S}$ & $\mathrm{K}$ sig \\
\hline$\sum 1$ & 68 & 32 & 100 & 70.91 & 16.11 & -0.10 & 0.05 .28 \\
\hline 2 & 59 & 49 & 108 & 84.26 & 13.18 & -0.63 & 0.86 .34 \\
\hline 3 & 59 & 43 & 102 & 82.84 & 16.27 & -0.88 & 0.42 .25 \\
\hline
\end{tabular}

$\sum 1=$ family function score

$\sum 2=$ predictors of the quality of family functioning score

$\sum 3=$ certain aspects of the educational function score

\section{Asymptotic significances} test.

Exact significance is displayed for this

Although there is no statistically significant difference in the estimation of the significance of a family function in the modern society, the predictors of the quality of family functioning and the aspects of the educational function of the family, some participants retained contradictory opinions even after the discussion. Theologians persisted in emphasizing the religious and patriotic functions of the family, diminishing the importance of socio-economic status on the conditions of childbirth and the educational function of the family. Psychiatrists and individual pedagogues emphasize the question of discipline as a family's educational function.

\section{Parenting}

After the analysis of family functions, predictors of a quality family life as a reference framework for the educational function of family, the research participants pointed out the importance of parenting quality. Parenting is justifiably interpreted as a concept, rather than an isolated role of an individual. Quality parenting implies knowing and understanding of a child and the creation of optimal responses to their developmental and psychophysical needs (Stegeman and Costongs, 2012). Competent and responsible parents contribute in great measure to the quality of the child's growing up (Belsky, 2014; Zygmunt-Fillwalk, 2011). In order to create a stimulating social environment and achieve high-quality interactions with children, the parent must activate their personal and external resources in guiding the child through the process of daily maturing (Ljubetić, 2012, p. 24). All this requires parents' responsiveness.

The starting point of understanding parenting as a skill that is not innate opens space for parental education. Research participants have generated the view that parents need to be involved in some form of education before they become parents $(\mathrm{M}=4.12 ; \mathrm{SD}=1.01$ for the whole sample). This points to the obligation of state policy to initiate education for parents through the educational and social institutions of the system $(\mathrm{M}=3.94 ; \mathrm{SD}=0.96)$ for which no consensus was achieved. Research participants (whole sample) estimate that:

- Parental education contributes to the quality of upbringing and education in the family only if the parents are personally, intrinsically motivated for a quality, effective parenting $(\mathrm{M}=4.18 ; \mathrm{SD}=0.81)$.

- Quality parenting workshops (as a form of parental education) are useful as an incentive for self-evaluation of personal behaviours $(\mathrm{M}=4.36 ; \quad \mathrm{SD}=0.78)$ and are purposeful only if they stimulate the process of working on oneself $(\mathrm{M}=4.12 ; \mathrm{SD}=0.85)$.

Participants of this research agree with the view that insisting on parental education would limit the fundamental human rights to freedom of choice. At the same time, they are unsure if the knowledge (that individuals could potentially acquire) would be positively associated with the development of parental competences. Although the attitude of most authors that a quality and responsible parenting can be taught cannot be ignored (Ljubetić, 2012; Petani 2011), Bennett and Grimley (2001) claim that in the contemporary world it is getting increasingly difficult to motivate 
parents to participate in education. The lack of interest in the development of parental competences is possibly a consequence of the parents' overburden with existential problems and intensive changes in society.

Through an anonymous discussion, the participants have unanimously concluded that the quality of (extra) marital partnership is not a prerequisite for quality parenting. Some parents, faced with a bad relationship with their partner, develop additional efforts to be good parents. They also emphasize that single parents can be good parents. Unfortunately, recent research shows that single-parent families usually have a difficult economic status, which may have a negative impact on the quality of parenting.

Through an anonymous discussion, a view has been generated that Institutional childcare for children of early and preschool age organized by companies (corporate kindergartens) can havenegative consequences in terms of upbringing in the long run, because this usually means the long-term separation of children from their families. Ninety seven percent of the research participants agree with this statement. This assumption is in accordance with recent research that links (long-term) exclusion of children from family life with long-term adverse outcomes, especially socioemotional difficulties (Vendell et al., 2010), and economically disadvantaged family status with dysfunctional parents and poorer achievements of children (Matejević and Đorđević, 2019; Zygmunt-Fillwalk, 2011).

Research participants agree that quality growing up means that early and preschool children primarily need a safe emotional attachment between them and their parents, as well as stable economic status and social inclusion of the family. An appropriate social support and a support from the state can contribute to the quality of parenting and indirectly, the quality of growing up within a family.

\section{CONCLUSIONS}

Family in Croatia, in accordance with the global social changes, gradually transforms its structure (interpreted as relationships between members), functions by which meets its members' needs and ways of functioning (mutual interactions, ways of spending time together, distribution of power and problem solving). Changes of relationships among family members, dynamics and ways that meet family functions are expected, but they are not linear, casual or time predictable.

It is certain that these dynamic processes shape the conditions of growing up in the family and have an impact on its development, upbringing, and education.

The overview of opinion polls, taken by professionals, on the family in Croatia suggests that there is no consensus on the unambiguous definition of family.

This results in conflicts in the public sphere - the rift of legal determinations, scientific and ideological interpretations. Illiberal tensions are strengthening which is recognizable in the extreme estimations provided by research participants. For example, the family is defined as a community of parents and (biological) children and certain educational aspects of the family are being diminished. However, relative aspects - emotional connection, attachment and communication among family members, have been singled out as the predictors of quality family functioning. The development of personality and socialization of children have been singled out as the most significant aspects of the educational function of family. At the same time, it is emphasized that all family functions have an upbringing and educational impact on children in the sense of transferring knowledge, values, norms, and behaviours.

The family, as a community in the society, is also determined by the culture of that society, social and economic processes, and social norms. Family norms, principles, and behaviours can be different from the society in which the family exists. Although the country is exposed to a long-lasting economic crisis, conservative attitudes are strengthening in Croatia. Research participants estimate that the patriotic and religious functions are the least significant family functions. Theologians in both subsamples retain a controversial attitude. The psychological, social, and upbringing functions of family have been singled out as the most significant permanent family functions. Economic family function, as one of the oldest family functions, becomes a significant predictor of the quality of parenting and children's outcomes. Interestingly, for most of the topics of joint discussion, there was no statistically significant difference found between the research participants - scientists and practitioners.

This study did not cover all family processes (such as the problem of abuse in the family) or any of the family policies defined by government (such as social security 
means). Nevertheless, basic family settings and upbringing and educational aspects of growing up in the family have been pointed out. A society geared towards democratic development, respect for the rights of the individual and the long-term welfare of the children should recognize the importance of quality family functioning. An insight into the real quality of family functioning in Croatia would only be possible by conducting a longitudinal study on a stratified sample of all family structures.

\section{ACKNOWLEDGEMENTS}

This artical is part of the preparatory research of scientific project „Empowering a family to develop positive relationships and family coherence /uniri-drustv-186/1132zlokovic" , with support of the University of Rijeka.

The authors are grateful to all participants of the research for their selfless support. By participating in the anonymous group discussion, participants expressed and arguments from different points of views. Their openness within the discussion has contributed to understanding the current functioning of families in Croatia.

\section{Conflict of interests} interest.

The authors declare no conflict of

\section{REFERENCES}

Amato, P. R. (2012). The well-being of children with gay and lesbian parents. Social Science Research, 41, 771-774. https://doi.org/10.1016/j. ssresearch.2012.04.007

Bejaković, P. (2010). Osobna prezaduženost. [Personal over-indebtedness]. Zagreb: Institut za financijska istraživanja

Belsky, D., Caspi, A., Arseneault, L., Bliedorn, W., Goodman, M., Houts, R., \& Moffitt, T. (2012). A test of diathesis-stress theories of the etiology of borderline personality disorder in a birth cohort of 12 year old children. Development and Psychopathology, 24(01), 251-265. https://doi. org/10.1017/S0954579411000812

Belsky, J. (2014). Social-contextual determinants of parenting. In R.E. Tremblay, M. Boivin, \& R. De. V. Peters (Eds.), Encyclopedia on Early Childhood Development [online], Montreal: Centre of Excellence for Early Childhood Development and Strategic Knowledge Cluster on Early Child Development. http://www.childencyclopedia.com/parenting-skills/accordingexperts/social-contextual-determinantsparenting

Bennett, J., \& Grimley, L. K. (2001). Parenting in global communitty: A cross - cultural international perspective. In M.J. Fine \& S.W. Lee (Eds.), Handbook of Diversity in Parent Education (pp.97-132). Accademic Press. https://doi. org/10.1016/B978-012256483-3/50006-X

Croatian Bureau of Statistics (2013). Popis stanovništva 2011. http://www.dzs.hr/Hrv/censuses/ census2011/censuslogo.htm

Croatian Bureau of Statistics (2018). Migracije stanovništva Republike Hrvatske u 2017. [Migration of the Croatian population in 2017]. https://doi.org/10.1055/s-0038-1641696

Croatian Bureau of Statistics (2018). Pokazatelji siromaštva $i$ socijalne isključenosti u 2017. [Poverty and social exclusion indicators in 2017]. https://www.dzs.hr/Hrv_Eng/publicatio/ 2018/14-01-01 01 2018.htm

Croatian Institute of Public Health (2018). Izvješće - Pobačaji u zdravstvenim ustanovama u Hrvatskoj u 2017. [Report - Abortions in Health Care Facilities in Croatia in 2017] https:// www.hzjz.hr/periodicne-publikacije/izvjescepobacaji-u-zdravstvenim-ustanovama-uhrvatskoj-u-2017/

D'Addato, A. (2010). Promoting prevention and early intervention, Eurochild's contribution. The Federal Foundation Mother and Child for pregnant women in emergency situations, Germany. http://www.eurochild.org/fileadmin/ Communications/08 Articles\%20about $\% 20$ and $\% 20$ by $\% 20$ Eurochild $/ 2010 /$ Todays Children_are_Tomorrows_Parents_Dec2010. pdf

Dempsey, D. (2013). Same-sex parented families in Australia. Melbourne: Australian Institute of Family Studies. http://www.mengage.org.au/ MENGAGE/media/MediaLibraryOne/cfca18. pdf

Elkind, D. (1994). Ties that stress: The new family imbalance. Cambridge. MA: Harvard University Press.

European Commission (2018). Education and Trainig Monitor. https://ec.europa.eu/education/policy/ strategic-framework/et-monitor_en

Eurostat Statistics Explained (2018). People at risk of poverty or social exclusion. https://ec.europa.eu/ eurostat/statistics-explained/index.php/People at_risk_of_overty_or_social_exclusion

Green, $\bar{R} . A . \quad(\overline{2014})$. The Delphi technique in education research. SAGE and Open Access page, 4(2). http://journals.sagepub.com/doi/ pdf/10.1177/2158244014529773

Haralambos, M., \& Holborn, M. (2002). Sociologija: Teme $i$ perspektive. [Sociology: Topics and Perspectives]. Zagreb: Golden marketing.

Helfrich, C. M., \& McWey, L. M. (2014). Substance use and delinquency: High-risk behaviors as predictors of teen pregnancy among adolescents involved with the child welfare system. Journal of Family Issues, 35(10), 1322-1338. https://doi. org $/ 10.1177 / 0192513 X 13478917$

Johnson, M. K., \& Hitlin, S. (2017). Family (dis) advantage and life course expectations. Social Forces, 95(3), 997-1022. https://doi. org/10.1093/sf/sow094

Kalina, O., Geckova, A. M., Klein, D., Jarcuska, P., Orosova, O., van Dijk, J. P., \& Reijneveld, S. A. (2011). Psychosocial factors associated with sexual behaviour in early adolescence. The European Journal of Contraception \& 
Reproductive Health Care, 16(4), 298-306. https://doi.org/10.3109/13625187.2011.586076

Kovčo Vukadin, I., Novak, M., \& Križan, H. (2016). Zadovoljstvo životom: individualna i obiteljska perspektiva. [Life satisfaction: individual and family's perspective]. Kriminologija \& socijalna integracija: časopis za kriminologiju, penologiju i poremećaje u ponašanju, 24(1), 84115. https://doi.org/10.31299/ksi.24.1.4

Law on Social Welfare/ Zakon o socijalnoj skrbi. Croatia. Narodne novine, 157/13.

Ljubetić, M. (2012). Nosi li dobre roditelje roda?!: odgovorno roditeljstvo za kompetentno dijete. [Does the stork carry good parents?! Responsible parenting for a competent child]. Profil.

Matejević, M., \& Đorđević, M. (2019). Par enting style in the context of the conflict between parental and business roles. International Journal of Cognitive Research in Science, Engineering and Education (IJCRSEE), 7(1), 51-61. https://doi. org/10.5937/ijcrsee190105M

Miljković, D. (2010). Induced stressful situation and success in solving simple mathematical tasks. Odgojne znanosti, 12(2), 283-296. https://hrcak. srce.hr/68273

Ministry of Science and Education (2019). Dječji vrtići, popis. [List of kindergartens]. http://mzos.hr/ $\mathrm{dbApp} /$ pregled.aspx?appName $=$ Vrtici

Olson, D. (2011). FACES IV and the circumplex model: Validation study. Journal of marital and family therapy, 37(1), 64-80. https://doi.org/10.1111/ j.1752-0606.2009.00175.x

Petani, R. (2011). Odnos roditelj - dijete. In D. Maleš (Ed.) Nove paradigm ranogodgoja. [New paradigms of early care and education] (pp. 97 124). Zagreb: Filozofski fakultet Sveučilišta u Zagrebu, Zavod za pedagogiju.

Rogošić, S. (2015). Životno zadovoljstvo budućih odgojitelja: utjecaji socijalnog, ekonomskog i ljudskog kapitala obitelji. [Life satisfaction of future educators: the impacts of family as social, economic and human capital]. Napredak: časopis za pedagogijsku teoriju i praksu, 156(3), 233-252. https://hrcak.srce.hr/166177

Stegeman, I., \& Costongs, C. (2012). The Right Start to a Healthy Life: Levelling-up the Health Gradient Among Children, Young People and Families in the European Union-What Works?. Euro Health Net. http://eurohealthnet.eu/sites/eurohealthnet. eu/files/publications/right-start-healthy-lifelevelling-up-health-gradient-children.pdf

Swartz, T. T., McLaughlin, H., \& Mortimer, J. T. (2017). Parental assistance, negative life events, and attainment during the transition to adulthood. The Sociological Quarterly, 58(1), 91-110. https://doi.org/10.1080/00380253.2016.124689 8

Tatalović Vorkapić, S., \& Jelić Puhalo, J. (2016). Povezanost osobina ličnosti, nade, optimizma i zadovoljstva životom odgojitelja predškolske djece. [Correlation between personality traits, hope, optimism and life satisfaction of the preschool educators]. Napredak: časopis za pedagogijsku teoriju i praksu, 157(1-2), 205220. https://hrcak.srce.hr/177231

Tucker, C. J., Sharp, E. H., Van Gundy, K. T., \& Rebellon, C. J. (2017). Household chaos, relationships with parents and adolescents' future beliefs. Journal of Family Studies, 23(3),
229-242. https://doi.org/10.1080/13229400.201 5.1090327

van der Schaaf, M. F., \& Stokking, K. M. (2011). Construct validation of content standards for teaching. Scandinavian Journal of Educational Research, 55(3), 273-289. https://doi.org/10.10 80/00313831.2011.576878

Vandell, D. L., Belsky, J., Burchinal, M., Steinberg, L., Vandergrift, N., \& NICHD Early Child Care Research Network. (2010). Do effects of early child care extend to age 15 years? Results from the NICHD study of early child care and youth development. Child development, 81(3), 737-756. https://doi.org/10.1111/j.14678624.2010.01431.x

Visković, I. (2013). Međugeneracijski prijenos vrijednosti $\mathrm{s}$ roditelja na djecu adolescente $\mathrm{u}$ općini Tučepi. . [Intergenerational transfer of values from parents to adolescent children in Tučepi municipality]. Školski vjesnik: časopis za pedagogijsku teoriju i praksu, 62(2-3). https:// hrcak.srce.hr/105323

Visković, I. (2016). Mogućnosti primjene Delfi metode u pedagogijskim istraživanjima. [Possibilities of applying the Delphi method in pedagogical research]. Napredak: časopis za pedagogijsku teoriju i praksu, 157(1-2), 187-204. https:// hrcak.srce.hr/177230

Watzlawick, P. (1993). The language of change: Elements of therapeutic communication. WW Norton \& Company.

Widmer,E.D.(2016). Familyconfigurations: Astructural approach to family diversity. Routledge. https:// doi.org/10.4324/9781315581903

Zygmunt-Fillwalk, E. (2011). Building family partnerships: The journey from preservice preparation to classroom practice. Journal of Early Childhood Teacher Education, 32(1), 8496. https://doi.org/10.1080/10901027.2010.547 653 